\title{
Abscisic acid induced freezing tolerance in chilling-sensitive suspension cultures and seedlings of rice
}

Reiko Shinkawa ${ }^{1,2+}$, Aiko Morishita ${ }^{1,2 \dagger}$, Kumiko Amikura ${ }^{1,2 \dagger}$, Rika Machida ${ }^{1 \dagger}$, Hiroki Murakawa ${ }^{1,2}$, Kazuyuki Kuchitsu ${ }^{2}$ and Masaya Ishikawa ${ }^{1 *}$

\begin{abstract}
Background: The role of abscisic acid (ABA) as a possible activator of cold acclimation process was postulated since endogenous levels of ABA increase temporarily or constitutively during cold-hardening. Exogenous application of ABA has been known to induce freezing tolerance at ambient temperatures in in vitro systems derived from cold hardy plants. Yet, some cell cultures acquired much greater freezing tolerance by ABA than by cold whilst maintaining active growth. This raises questions about the relationships among ABA, cold acclimation and growth cessation. To address this question, we attempted to 1) determine whether exogenous ABA can confer freezing tolerance in chilling-sensitive rice suspension cells and seedlings, which obviously lack the mechanisms to acquire freezing tolerance in response to cold; 2) characterize this phenomenon by optimizing the conditions and compare with the case of cold hardy bromegrass cells.
\end{abstract}

Results: Non-embryogenic suspension cells of rice suffered serious chilling injury when exposed to $4^{\circ} \mathrm{C}$. When incubated with $A B A$ at the optimal conditions (0.5-1 g cell inoculum, $75 \mu \mathrm{M} \mathrm{ABA}, 25-30^{\circ} \mathrm{C}, 7-10$ days), they survived slow freezing $\left(2^{\circ} \mathrm{C} / \mathrm{h}\right)$ to $-9.0 \sim-9.3^{\circ} \mathrm{C}\left(\mathrm{LT} T_{50}: 50 \%\right.$ killing temperature) while control cells were mostly injured at $-3^{\circ} \mathrm{C}$ $\left(L T_{50}:-0.5 \sim-1.5^{\circ} \mathrm{C}\right)$. Ice-inoculation of the cell suspension at $-3^{\circ} \mathrm{C}$ and survival determination by regrowth confirmed that $\mathrm{ABA}$-treated rice cells survived extracellular freezing at $-9^{\circ} \mathrm{C}$. ABA-induced freezing tolerance did not require any exposure to cold and was best achieved at $25-30^{\circ} \mathrm{C}$ where the rice cells maintained high growth even in the presence of $A B A$. ABA treatment also increased tolerance to heat $\left(43^{\circ} \mathrm{C}\right)$ as determined by regrowth. $A B A-$ treated cells tended to have more augmented cytoplasm and/or reduced vacuole sizes compared to control cultures with a concomitant increase in osmolarity and a decrease in water content. ABA-treated (2-7 days) in vitro grown seedlings and their leaves survived slow freezing to $-3^{\circ} \mathrm{C}$ with only marginal injury $\left(L T_{50}:-4^{\circ} \mathrm{C}\right)$ whereas untreated seedlings were killed at $-3^{\circ} \mathrm{C}\left(L T_{50}:-2^{\circ} \mathrm{C}\right)$.

Conclusions: The results indicate that exogenous ABA can induce some levels of freezing tolerance in chillingsensitive rice cells and seedlings, probably by eliciting mechanisms different from low temperature-induced cold acclimation.

Keywords: ABA (abscisic acid), Cold hardiness, Cell culture, Freezing injury, Freezing tolerance, Chilling injury, Rice (Oryza sativa)

\footnotetext{
* Correspondence: isikawam@affrc.go.jp

${ }^{\dagger}$ Equal contributors

${ }^{1}$ Division of Plant Sciences, National Institute of Agrobiological Sciences,

Kannondai 2-1-2, Tsukuba 305-8602, Ibaraki, Japan

Full list of author information is available at the end of the article
} 


\section{Background}

Temperate cold hardy plants cold-acclimate or acquire cold hardiness (resistance to subfreezing temperatures; for more precise definitions, please see the Definition Section) in response to low temperatures alone or in combination with short photoperiods [1]. The molecular mechanisms involved in the induction of cold hardiness at the cellular level are still not well understood. Several studies have suggested that ABA may be involved in the initiation of cold acclimation. Endogenous levels of ABA have been demonstrated to increase temporarily during the initial stages of cold hardening [2-4] or constitutively during cold acclimation of cold hardy species [5]. Exogenous application of ABA is known to increase freezing tolerance of cold hardy plants, suspension cultures and callus cultures derived from plants capable of cold acclimation [6-9]. These findings have led to the hypothesis that cold acclimation is activated through the action of ABA; i.e. that low temperature brings about an increase in $\mathrm{ABA}$, which triggers the activation of cold hardiness mechanisms [6].

In accordance with this hypothesis, ABA-deficient mutant (aba1) and ABA-insensitive mutant (abi1) of Arabidopsis plants following exposure to cold-acclimating conditions were less cold hardy compared to wild type plants [10-12]. But the results have to be interpreted with caution as these mutants have much less vigor than wildtype plants, which may result in lower capability of cold acclimation [13]. Analyses of COR gene expression in these mutants and wild-type plants revealed that some COR genes were highly responsive to exogenous ABA but their expression by low temperature was not necessarily mediated by ABA $[11,14]$. More recently, molecular analyses of low temperature-responsive genes in Arabidopsis have revealed that there are ABA-dependent and ABAindependent transcriptional pathways $[15,16]$ and even cross-talks between these pathways [17]. The role of ABA in activation of low temperature responses is considered to be minor than it was thought [13]. Yet, questions still remain unanswered as to how $\mathrm{ABA}$ alone can induce high levels of freezing tolerance in some plant systems and how it should be interpreted, especially with regard to coldinduced freezing tolerance.

Induction of freezing tolerance by exogenous $\mathrm{ABA}$ in cold hardy bromegrass suspension cells has attracted attention as it can induce high levels of freezing tolerance $\left(\mathrm{LT}_{50}:-28 \sim-35^{\circ} \mathrm{C}\right)$ at non-hardening temperature $(25-$ $30^{\circ} \mathrm{C}$ ) in a rather short period of time $[7,18]$. Not only freezing tolerance, heat, salt and osmotic stress tolerance were simultaneously induced by ABA (cross-adaptation) [18]. Comparison of low temperature-induced freezing tolerance and ABA-induced freezing tolerance may provide a unique approach to understanding cold hardiness mechanisms. Physiological, morphological analyses [7], gene expression and protein analyses [19-21] have all shown that ABA-induced freezing tolerance is different from the one induced by low temperature. Ishikawa et al. [7] considered that behavior of bromegrass cells during induction of freezing tolerance by ABA was similar to that of the seed formation process.

Rice originates from tropical and subtropical areas and is sensitive to chilling temperatures (cool temperature ranges above $0^{\circ} \mathrm{C}$ ) at various developmental stages such as booting, flowering and seedling stages [22,23]. Seedlings suffer injuries upon exposure to $5-10^{\circ} \mathrm{C}$ for $3-11$ days [24-26]. Callus cultures of rice are also known to suffer chilling injury at $5^{\circ} \mathrm{C}$ [27]. Since rice plants suffer injuries at cool temperature ranges suitable for cold-hardening of cold-hardy plants, they are considered unable to acclimate to cold and to be freezing-sensitive [25]. More recently, it has been demonstrated that rice is capable of reducing chilling injuries $\left(4-7\right.$ days exposure to $4^{\circ} \mathrm{C}$ ) by prior exposure to $12^{\circ} \mathrm{C}$ for 2 days, more pronouncedly in japonica cultivars than indica cultivars [28]. However, this does not mean that rice can withstand prolonged exposure to chilling temperatures or can further acclimate to freezing temperatures. This can be easily proven by observing japonica rice cultivars in field conditions at Tsukuba, ca. $50 \mathrm{~km}$ north-east of Tokyo, Japan. After harvesting in the early autumn, new sprouts come out of the remaining rice stubble and grow to $10-15 \mathrm{~cm}$ tall in warm temperatures of October and November. These shoots seem to withstand transient exposure (daily or for several days) to chilling temperatures during this period but they are likely unable to acquire freezing tolerance in the autumnal conditions. They are eventually killed either by prolonged exposure to chilling temperatures and/or by frosts in late November or early December and are unable to overwinter in this area (none of them can regrow in the following spring).

It is of interest to check whether chilling-sensitive plants that lack the capability of cold acclimation (acquire freezing tolerance in response to cold) can attain freezing tolerance in response to ABA. To our knowledge, there has been no such attempt. This may enhance our understanding of ABA-induced freezing tolerance.

The objective of this study is to determine whether ABA can induce freezing tolerance in rice, a chilling-sensitive plant, which lacks low temperature-induced cold acclimation capability. The study was also intended to optimize culture conditions for inducing maximal freezing tolerance by $\mathrm{ABA}$ in rice and to physiologically characterize this system. The results were compared with cold-hardy bromegrass suspension cells to help understand the nature of ABA-induced freezing tolerance.

\section{Results}

Chilling sensitivity of rice suspension cells and effect of ABA

To check chilling sensitivity of rice suspension cells, cells were exposed to $4^{\circ} \mathrm{C}$ for up to 10 days in the presence or 
absence of $75 \mu \mathrm{M}$ ABA. Bromegrass suspension cells were also incubated in the same manner as a chilling tolerant control. Exposure of rice suspension cultures (without $\mathrm{ABA}$ treatment) to $4^{\circ} \mathrm{C}$ for more than 2 days greatly reduced the viability as determined by regrowth capacity, which indicated a high level of chillingsensitivity of rice cells (Figure 1A). Inclusion of ABA $(75 \mu \mathrm{M})$ in the medium reduced the chilling injuries of rice cells but only $30 \%$ of ABA-incubated cells survived after 10 days of incubation at $4^{\circ} \mathrm{C}$. In contrast, suspension cells of cold-hardy and chilling tolerant bromegrass did not suffer any injuries during 10 day-incubation at $4^{\circ} \mathrm{C}$ both in the presence and absence of ABA (Figure 1A). Continuous incubation of rice suspension cultures at $4^{\circ} \mathrm{C}$ resulted in drastically diminished growth in the 3 week period whilst that of bromegrass cultures increased fresh weight by $14 \%(+\mathrm{ABA})$ and $36 \%(-\mathrm{ABA})$ after 3 weeks (Figure 1B).

\section{Effect of $A B A$ on freezing tolerance of rice suspension cells}

To determine whether rice suspension cells can acquire freezing tolerance (not chilling tolerance) by incubation with $\mathrm{ABA}$, rice cultures (initiated from $1 \mathrm{~g}$ of cell inoculum) were incubated at $25^{\circ} \mathrm{C}$ for 7 days in the presence
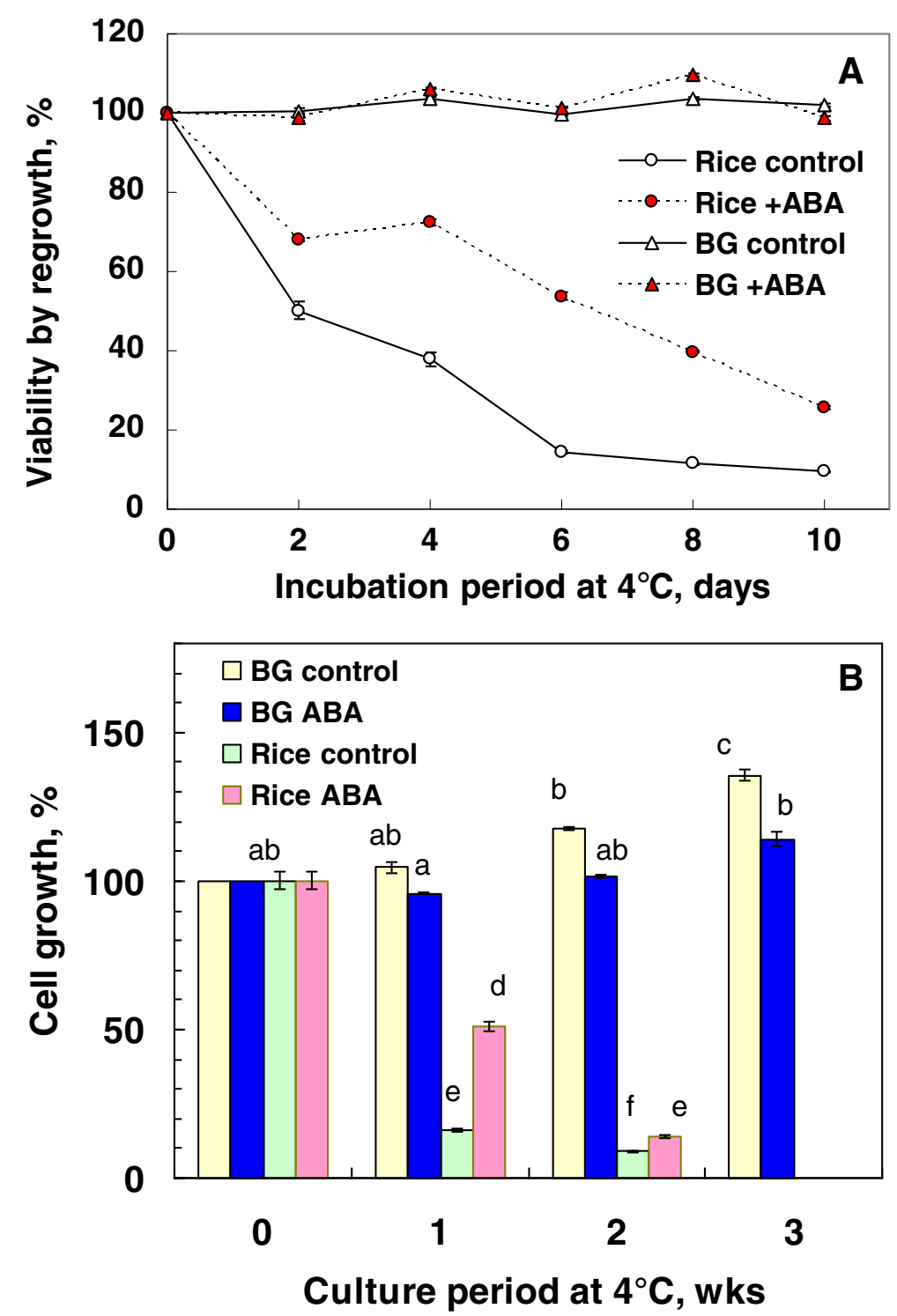

Figure 1 Chilling sensitivity of suspension cells of rice and bromegrass cultured at $4^{\circ} \mathrm{C}$ in the presence or absence of $75 \mu \mathrm{M}$ ABA (A) and growth of rice and bromegrass cells during prolonged culture at $4^{\circ} \mathrm{C}$ with or without $75 \mu \mathrm{M} \mathrm{ABA}(\mathrm{B})$. Rice or bromegrass cells ( $\left.0.25 \mathrm{~g}\right)$ inoculated in $12.5 \mathrm{~mL}$ of $\mathrm{N} 6$ medium or ER medium were incubated at $4^{\circ} \mathrm{C}$ in the presence or absence of $75 \mu \mathrm{M} \mathrm{ABA}$ for designated periods following 2 day pre-incubation at $25^{\circ} \mathrm{C}$. Survival of chilled cells was determined by regrowing the cells (non-stressed cells as the $100 \%$ control). Values indicated by different letters $(a-f)$ were significantly different $(a=0.05)$ using Tukey-Kramer multiple comparison analyses (Figure 1B). 
of $0,15,37.5,75 \mu \mathrm{M}$ ABA and harvested cells were used for freeze tests. Increasing concentrations of ABA allowed the cells to acquire higher levels of survival at freezing temperatures (Figure 2). The highest freezing tolerance $\left(\mathrm{LT}_{50}:-8.0^{\circ} \mathrm{C}\right)$ as determined by $\mathrm{TTC}$ reduction tests was obtained with $75 \mu \mathrm{M}$ ABA. Incubation of rice cells with $100 \mu \mathrm{M}$ ABA conferred a similar level of freezing tolerance $\left(\mathrm{LT}_{50}:-7.9^{\circ} \mathrm{C}\right)$ and $75 \mu \mathrm{M}$ ABA was likely the optimal concentration for inducing freezing tolerance in rice cells. This is similar to the optimal concentrations of other plant systems where ABA-induced cold hardiness was attempted [6-9]. Regrowth assays gave essentially similar freeze survival results (data not shown). At the beginning of the freeze tests $\left(-3^{\circ} \mathrm{C}\right)$, each test tube was ice-inoculated and equilibrated for $1 \mathrm{~h}$ before further cooling. Freezing of the cells in the medium (water) inside the tube was visually ascertained at this step and also at the designated temperature when the tube was taken out of the freezer. Thus the cell survival observed at freezing temperatures was not due to incidental supercooling but to tolerance of extracellular freezing at a slow cooling rate $\left(2^{\circ} \mathrm{C} / \mathrm{h}\right)$.

Time course analysis of freezing tolerance induction by ABA Chronological changes in freezing tolerance were followed with rice suspension cells cultured with or without $75 \mu \mathrm{M}$ ABA for up to 14 days. Incubation with ABA induced freezing tolerance $\left(\mathrm{LT}_{50}\right)$ of $-4.8^{\circ} \mathrm{C}$ in 3 days as determined by TTC assay (Figure 3 ). Induced level of freezing tolerance increased to $-9.3^{\circ} \mathrm{C}$ in 7 days and was maintained until 14 days $\left(-8.5^{\circ} \mathrm{C}\right)$. In contrast, the control cells harvested on day 3 and 7 did not tolerate freezing $\left(\mathrm{LT}_{50}\right.$ : -0.7 and $-0.3^{\circ} \mathrm{C}$, respectively) whilst on day 14 the cells acquired freezing tolerance of $-5.1^{\circ} \mathrm{C}$. Similar acquisition of freezing tolerance in control cells at the stationary stage of the growth curve has been observed in bromegrass suspension cells $[7,29]$.

Effect of cell inoculum size on ABA-induced freezing tolerance In the case of freezing tolerance induction by ABA in bromegrass suspension cultures, the amount of cells inoculated in the medium was one of the most influential factors determining the level of induced freezing tolerance [7]. To see whether this holds true with rice suspension cells, cultures initiated from $0.5,1$ and $1.5 \mathrm{~g}$ cells were grown in the presence or absence of $75 \mu \mathrm{M}$ ABA for 7 days at $25^{\circ} \mathrm{C}$ and the freezing tolerance induced was compared. The highest freezing tolerance $\left(\mathrm{LT}_{50}:-9.0^{\circ} \mathrm{C}\right)$ as determined by regrowth capacity was obtained when culture was initiated from $0.5 \mathrm{~g}$ cells, followed by $1 \mathrm{~g}$ and $1.5 \mathrm{~g}$ (Figure 4). Control cultures of rice suspension cells grown without $\mathrm{ABA}$ showed the lowest freeze survival $\left(\mathrm{LT}_{50}\right.$ : higher than $\left.-3^{\circ} \mathrm{C}\right)$ when culture was initiated from $0.5 \mathrm{~g}$ cells, followed by $1 \mathrm{~g}$ and $1.5 \mathrm{~g}$ (Figure 4). The greatest difference in freeze survival between ABA-treated cultures and control cultures was obtained with cultures initiated from $0.5 \mathrm{~g}$ of cells.

\section{Effect of incubation temperature on ABA-induced freezing tolerance}

In the case of bromegrass suspension cultures, the optimal temperature for inducing freezing tolerance by $\mathrm{ABA}$ was found to occur at 25 and $30^{\circ} \mathrm{C}$ among the temperatures tested $\left(5,10,15,20,25,30^{\circ} \mathrm{C}\right)$ and the level of freezing tolerance induced was proportionally related to the amount of growth achieved [7]. To check whether this holds true with rice suspension cells, rice suspension cells (initiated from $1 \mathrm{~g}$ of cells) were grown for 7 days with $75 \mu \mathrm{M}$ ABA at different incubation temperatures $\left(25,28,30^{\circ} \mathrm{C}\right)$. The highest freezing tolerance $\left(\mathrm{LT}_{50}:-9.3^{\circ} \mathrm{C}\right)$ was obtained at

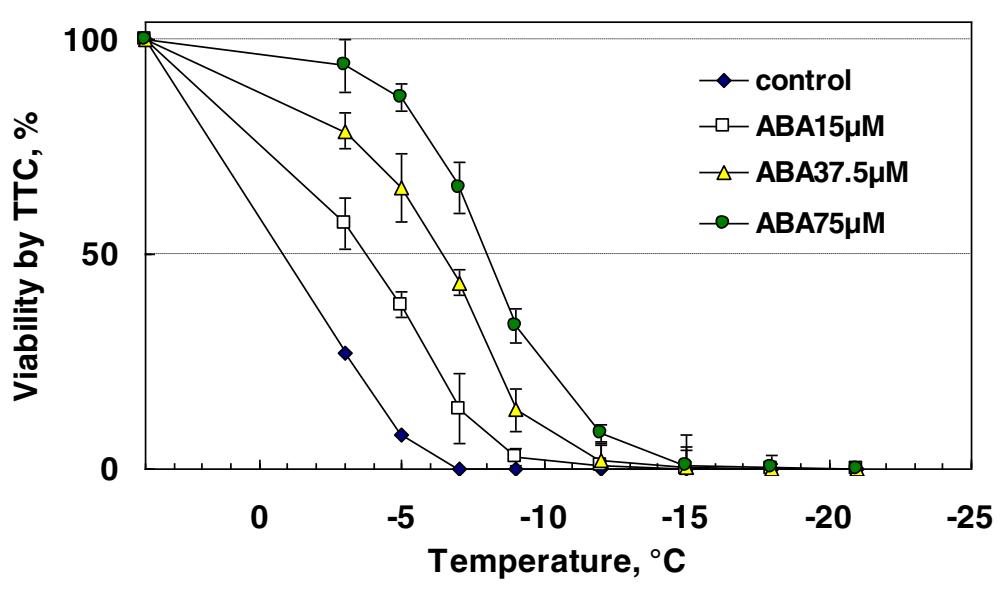

Figure 2 Freeze survival of rice suspension cells cultured in the presence of $\mathrm{ABA}(0-75 \mu \mathrm{M})$ for 7 days at $25^{\circ} \mathrm{C}(1 \mathrm{~g}$ cell inoculum in $\mathbf{5 0} \mathbf{~ m L}$ of medium). Freezing tests were done as described in the Methods and survival was determined by $\Pi T C$ (2,3,5-triphenyl tetrazolium chloride) reduction assays. 


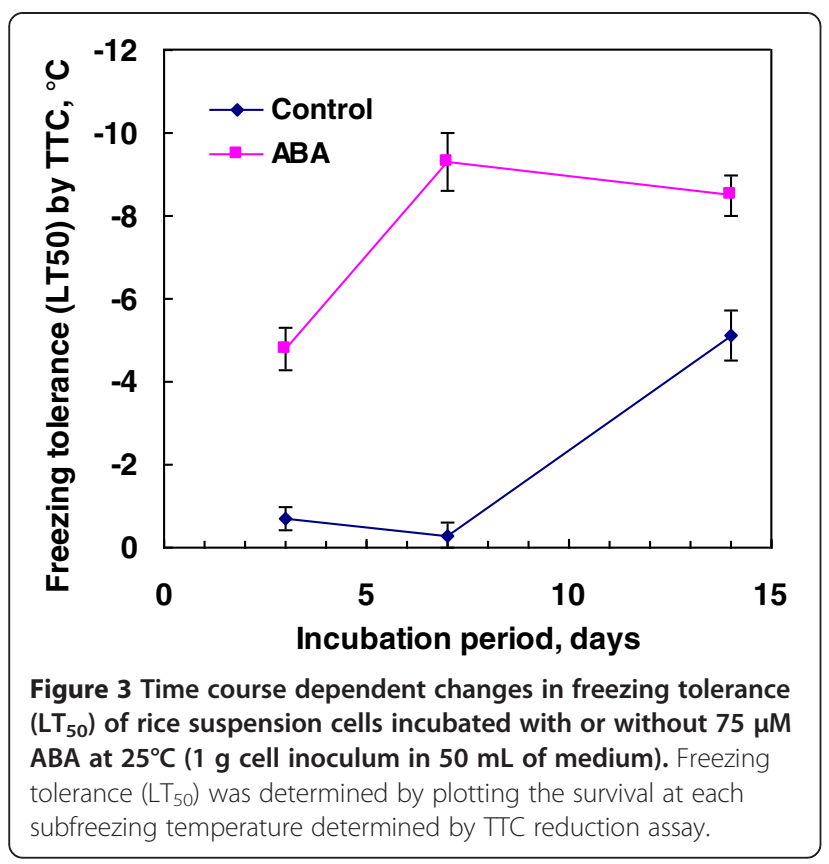

$28^{\circ} \mathrm{C}$, followed by $30^{\circ} \mathrm{C}\left(\mathrm{LT}_{50}:-8.5^{\circ} \mathrm{C}\right)$ then $25^{\circ} \mathrm{C}\left(\mathrm{LT}_{50}:-7.9^{\circ} \mathrm{C}\right)$ (Figure 5A). At these temperatures, rice cells showed considerable growth in the presence of ABA (but not as much as the control cells) and the level of ABA-induced freezing tolerance was greater where there was more growth $\left(28>30^{\circ} \mathrm{C}>25^{\circ} \mathrm{C}\right.$ ) (Figure $5 \mathrm{~B}$ ).

\section{Effect of light, shaker speed and flask size on ABA-induced freezing tolerance}

Oxygen supply is an important factor for cold acclimation as it requires ATP and $\mathrm{NAD}(\mathrm{P}) \mathrm{H}[1]$. Shaker speed may limit oxygen supply to suspension cells but culture agitation between 85 and $120 \mathrm{rpm}(1 \mathrm{~g}$ cell inoculum in $50 \mathrm{~mL}$ of medium at $25^{\circ} \mathrm{C}$ ) did not greatly influence the level of freezing tolerance induced by ABA (data not shown). To check whether there is any effect of flask sizes that may also affect oxygen supply to suspension cells, $2.5 \mathrm{~g}$ of cells were inoculated into $250 \mathrm{~mL}$ of medium with or without $\mathrm{ABA}$ in $1 \mathrm{~L}$ flasks, instead of $0.5 \mathrm{~g}$ of cells inoculated into $50 \mathrm{~mL}$ of medium in $200 \mathrm{~mL}$ flasks (the same cell inoculum/medium ratio). However, the use of $1 \mathrm{~L}$ flask altered the level of ABA-induced freezing tolerance $\left(\mathrm{LT}_{50}\right)$ only marginally $\left(-9.3^{\circ} \mathrm{C}\right)$ compared to the $200 \mathrm{~mL}$ flask system $\left(\mathrm{LT}_{50}:-9.0^{\circ} \mathrm{C}\right)$ as determined by regrowth assays (Figure 6). An improved survival $(16 \%)$ at $-12^{\circ} \mathrm{C}$ was obtained by the use of $1 \mathrm{~L}$ flask system.

\section{Maximal freeze survival induced by $A B A$ and effect of inclusion of $3 \%$ sucrose in the freezing medium on freezing tolerance}

The results presented in Figures 4 and 5 imply that a better freeze survival may be obtained by incubation of $0.5 \mathrm{~g}$ cells at $28^{\circ} \mathrm{C}$ in $50 \mathrm{~mL}$ medium $(+75 \mu \mathrm{M} \mathrm{ABA})$. However, there was no further improvement in the freezing tolerance $\left(\mathrm{LT}_{50}:-9.0^{\circ} \mathrm{C}\right)$ under this condition (Figure 6). These results suggest that the maximal freezing tolerance level acquired by $\mathrm{ABA}$ treatment in rice suspension cells are in the range of $-9 \sim-9.3^{\circ} \mathrm{C}$.

Exogenous sucrose is known to be a good cryoprotectant [1]. We investigated whether this is also the case with rice suspension cells. The use of $3 \%$ sucrose, instead of water, for the freezing medium improved the level of freezing tolerance of control $\left(\mathrm{LT}_{50}:-5.7^{\circ} \mathrm{C}\right)$ and $\mathrm{ABA}$-treated rice cells $\left(\mathrm{LT}_{50}:-11.3^{\circ} \mathrm{C}\right)$ compared to freezing tolerance determined

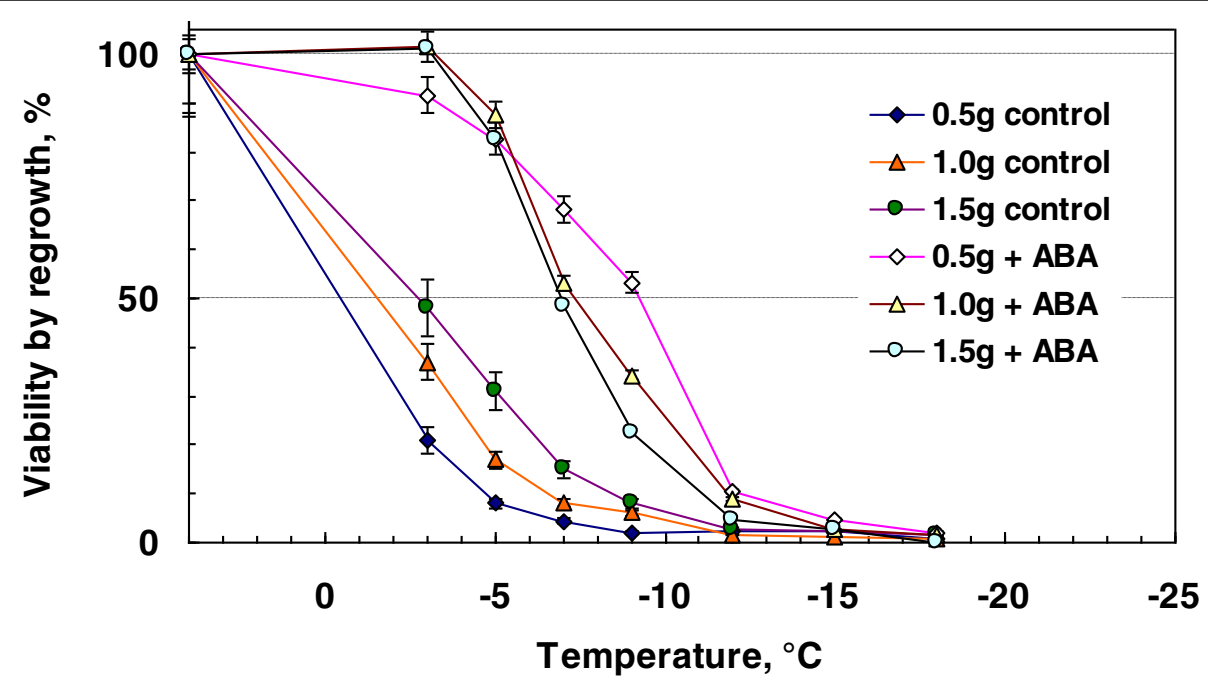

Figure 4 Effect of cell inoculum size on freezing tolerance of rice cells incubated with or without ABA. Cell cultures initiated from 0.5$1.5 \mathrm{~g}$ of rice cells in $50 \mathrm{~mL}$ of medium were incubated at $25^{\circ} \mathrm{C}$ for 7 days with or without $A B A(75 \mu \mathrm{M})$. Freezing tolerance was determined as described in the Methods and survival was determined by regrowth. 

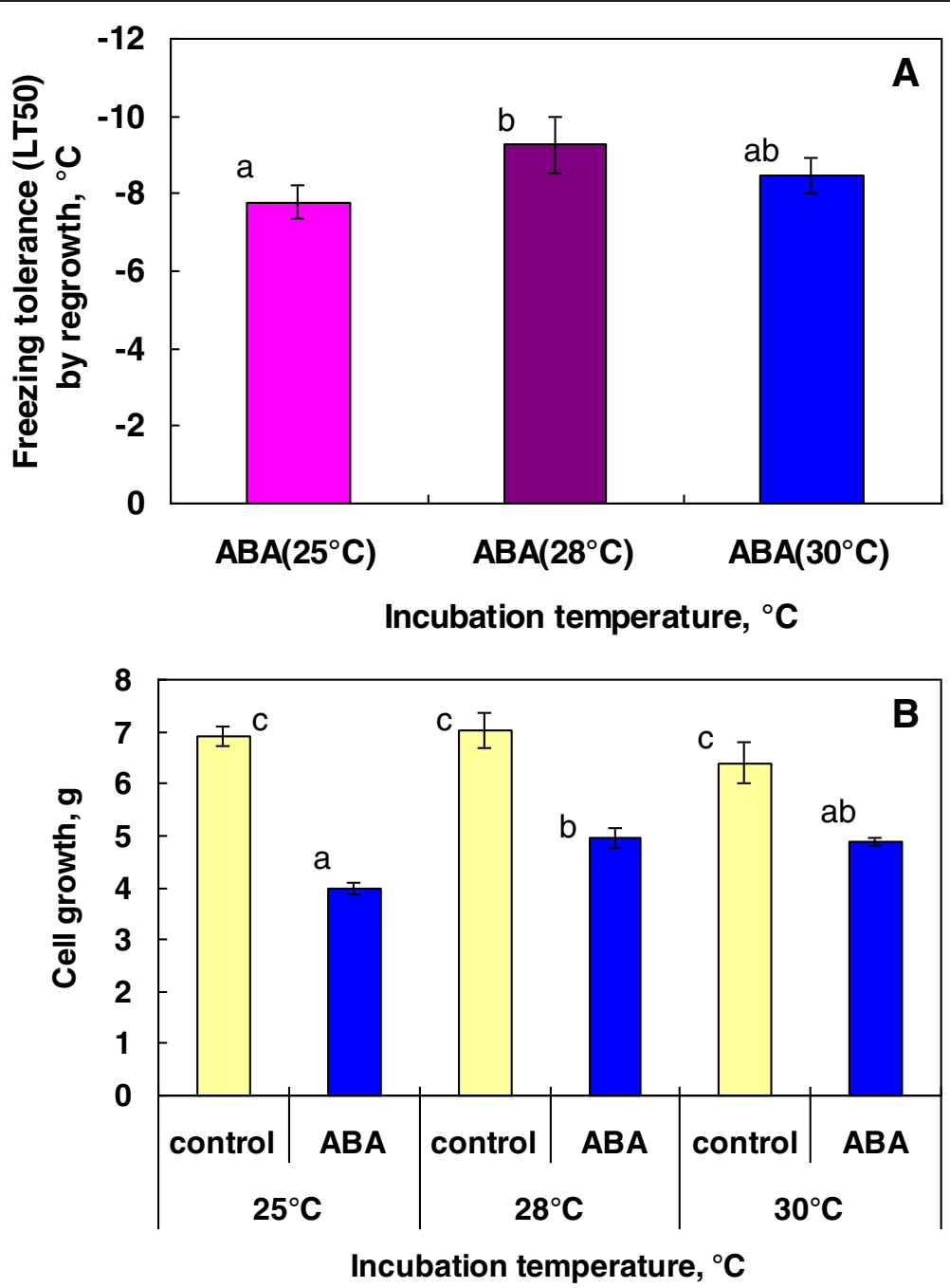

Figure 5 Effect of culture temperatures on freezing tolerance induced by exogenous $A B A(A)$ and growth (B) of rice suspension cells. Cell cultures $\left(1 \mathrm{~g}\right.$ cell inoculum in $50 \mathrm{~mL}$ medium) were incubated at 25,28 or $30^{\circ} \mathrm{C}$ for 7 days with or without $75 \mu \mathrm{M}$ ABA. Freeze survival was determined by regrowth and cell growth on fresh weight basis was measured as detailed in the Methods. Values indicated by different letters (a-c) significantly differed at 5\% level using Tukey-Kramer multiple comparison analyses.

in plain water $\left(\mathrm{LT}_{50}\right.$ of control and ABA-treated cells: -0.6 and $-9.0^{\circ} \mathrm{C}$, respectively) as assayed by regrowth.

\section{Effect of $A B A$ on heat tolerance of rice suspension cells} To check whether ABA can induce stress tolerance other than freezing, heat tolerance was determined with rice cells grown for 7 days with or without $75 \mu \mathrm{M}$ ABA. The harvested cells were exposed directly to $43^{\circ} \mathrm{C}$ for 0 to $180 \mathrm{~min}$ without heat shock pretreatment. ABAtreated cells showed much higher survival throughout the treatment period (20-180 min) compared to control cells as determined by regrowth capacity (Figure 7).

\section{Changes in physiological and morphological parameters} of rice cells induced by $A B A$

To reveal physiological changes induced by ABA treatment, we determined osmolarity and water content of rice cells incubated with or without $\mathrm{ABA}$ for 7 days at $25^{\circ} \mathrm{C}$. Since suspension cells were incubated in liquid media, the cells were rich in the intercellular water, which was not easy to remove completely. We centrifuged the harvested rice cells at $1500 \mathrm{rpm}$ for $10 \mathrm{~min}$ to remove the majority of the intercellular water prior to determination of water content and osmolarity. ABAtreated cells had a water content of $395 \%$ on dry weight basis, which was ca. $18 \%$ reduction compared to the control cells (481\% dry weight) (Figure 8A). Meanwhile, the ABA-treated cells had a slightly (by $11 \%$ ) increased osmolarity ( $282 \mathrm{mOsm} / \mathrm{kg}$ ) compared to the control cells $(255 \mathrm{mOsm} / \mathrm{kg}$ ) (Figure 8B). Osmolarity in this range likely contributes to freeze point depression of only $0.5^{\circ} \mathrm{C}$, which is not sufficient for avoiding freezing of cellular water at $-3^{\circ} \mathrm{C}$ or lower. The difference in the osmolarity 


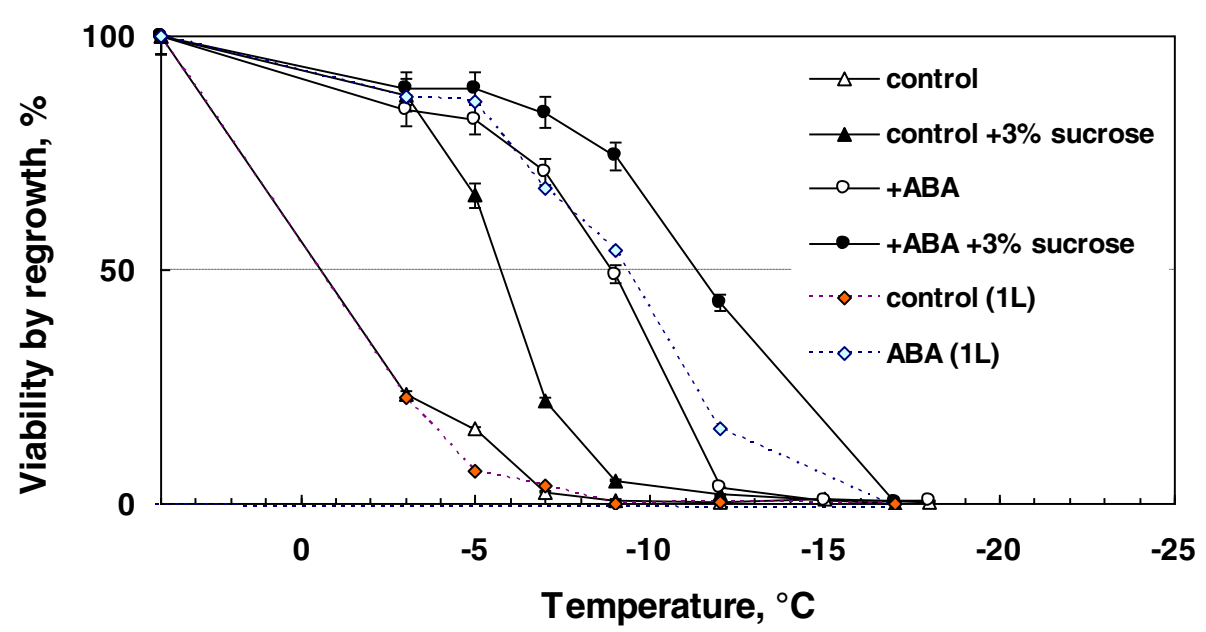

Figure $6 \mathrm{Effect}$ of $3 \%(\mathrm{w} / \mathrm{v})$ of sucrose included in the freezing medium on freezing tolerance of rice suspension cells. Cell cultures $(0.5 \mathrm{~g}$ cell inoculum in $50 \mathrm{~mL}$ medium) were incubated at $28^{\circ} \mathrm{C}$ for 7 days with or without $75 \mu \mathrm{M} \mathrm{ABA}$. Harvested cells were frozen either in $0.1 \mathrm{~mL}$ of $3 \%$ sucrose or in $0.1 \mathrm{~mL}$ of sterile water. Freeze survival was determined by regrowth. Freeze survival of cell cultures $(2.5 \mathrm{~g}$ cell inoculum in $1 \mathrm{~L}$ medium) incubated at $28^{\circ} \mathrm{C}$ with or without $75 \mu \mathrm{M} \mathrm{ABA}$ (no sucrose in the freezing medium) was also shown for comparison.

was not large enough to explain the differences in freezing tolerance between control and ABA-treated cells.

To determine any changes in the cellular structure induced by $A B A$ treatment, we isolated protoplasts from the rice cells incubated with or without $75 \mu \mathrm{M}$ ABA for 7 days at $25^{\circ} \mathrm{C}$ for observation under microscopy. ABAtreated cultures were rich with cells that had more augmented cytoplasm with increased particles and/or reduced vacuole sizes whereas control cultures had a higher frequency of well-vacuolated cells (Figure 9).

\section{Effect of $A B A$ on freezing tolerance of in vitro grown rice seedlings}

To see whether ABA can induce freezing tolerance in plant systems other than cell cultures, we determined freezing tolerance of young rice seedlings and their leaves treated with or without ABA. When leaves of control rice seedlings (grown for 8 days at $25^{\circ} \mathrm{C}$ ) were exposed to slow freezing to $-3^{\circ} \mathrm{C}$ following ice-inoculation at $-1^{\circ} \mathrm{C}, 82 \%$ of the tissues were injured $\left(\mathrm{LT}_{50}:-2^{\circ} \mathrm{C}\right)$ as shown by leakage tests (Figure 10B). Leaves of seedlings incubated with ABA for 2 days or more had reduced injuries (15\%) when slowly frozen to $-3^{\circ} \mathrm{C}$ but showed over $70 \%$ injury at $-5^{\circ} \mathrm{C}\left(\mathrm{LT}_{50}:-4^{\circ} \mathrm{C}\right)$. In accordance with leakage test results, whole rice seedling that had been incubated with $75 \mu \mathrm{M}$ ABA 4 days survived slow freezing to $-3^{\circ} \mathrm{C}$ with the ability to regrow whilst they were unable to regrow after exposure to $-5^{\circ} \mathrm{C}$ (Figure 10A). In contrast, control rice seedlings (without ABA treatment) exposed to slow freezing to $-3^{\circ} \mathrm{C}$ were unable to regrow

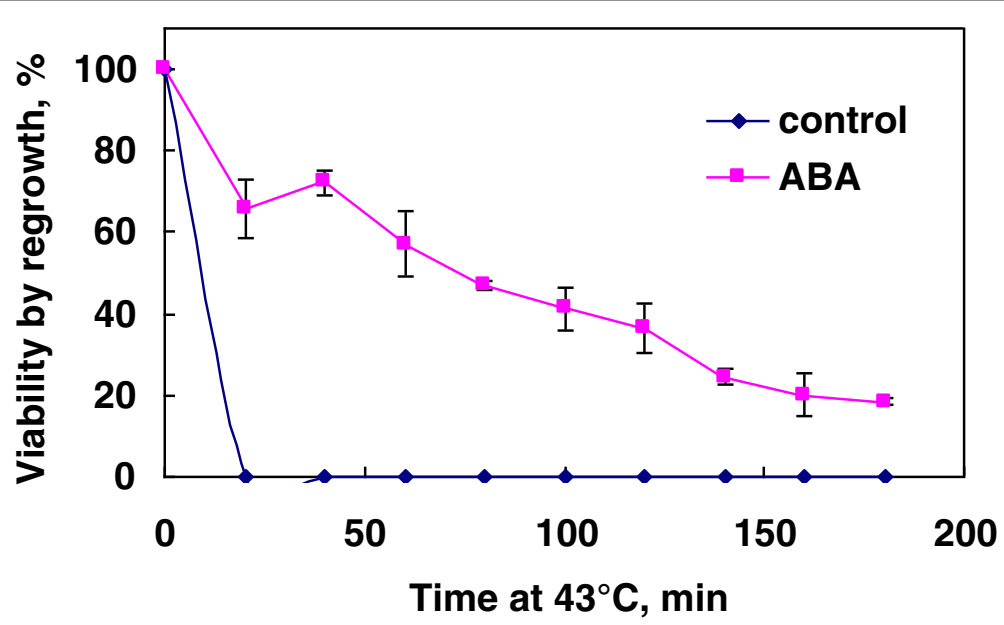

Figure 7 Heat tolerance of rice suspension cells incubated in the presence or absence of $75 \mu \mathrm{M} \mathrm{ABA}$ for 7 days at $25^{\circ} \mathrm{C}(1 \mathrm{~g}$ cell inoculum). Survival of cells directly exposed to $43^{\circ} \mathrm{C}$ for $0-180 \mathrm{~min}$ (without heat shock pretreatment) was determined by regrowth capacity compared to that of non-stressed cells. 


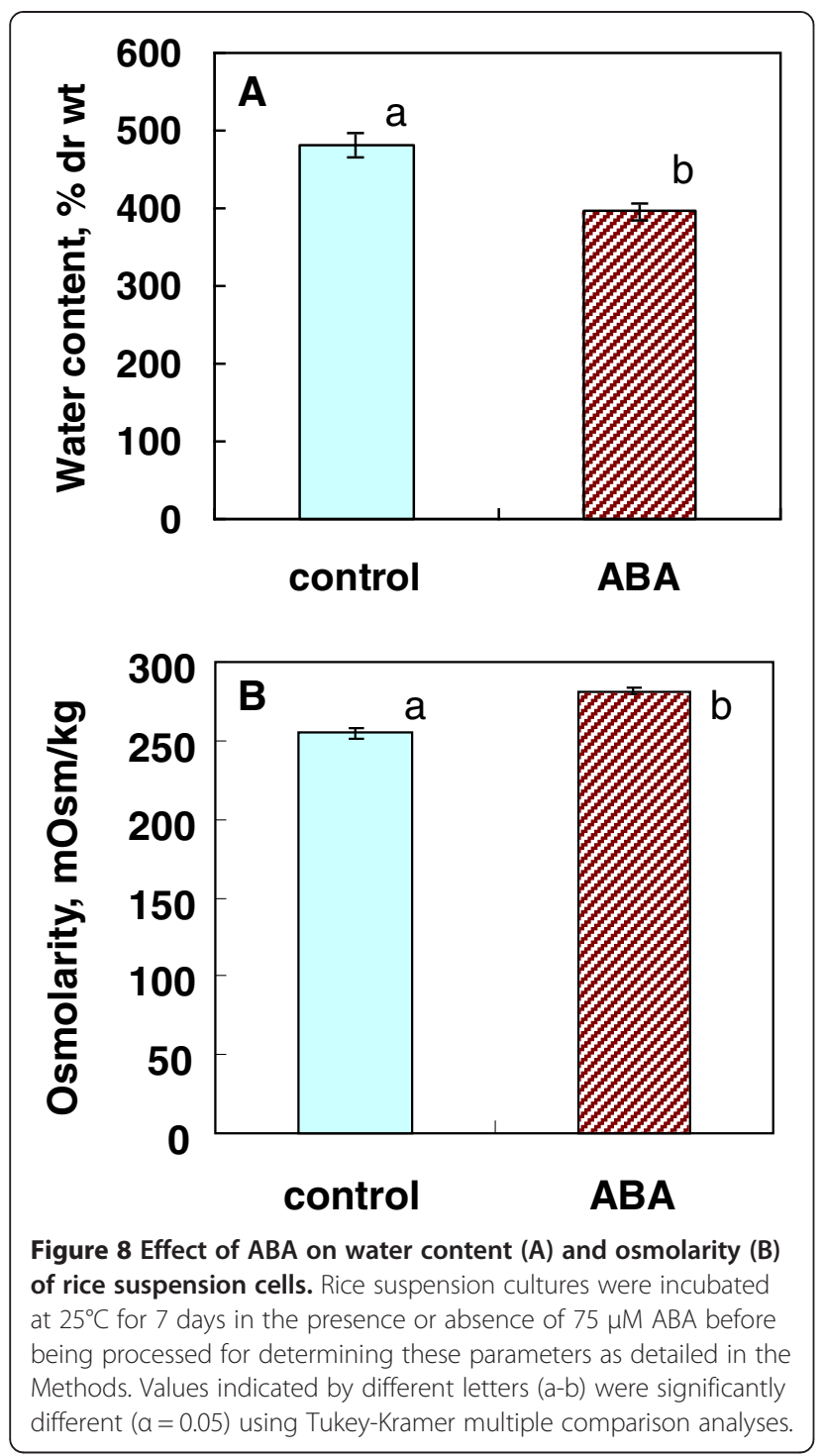

although they retained some green in the leaf sheath (Figure 10A). In the freeze tests, each test tube was iceinoculated at $-1^{\circ} \mathrm{C}$ and held there for $30 \mathrm{~min}$ or $1 \mathrm{~h}$ before further cooling. Freezing of the tissues in suspension medium (water) was visually ascertained at this step and also at the designated temperature when the tube was taken out of the freezer. Thus the tissue survival at freezing temperatures was not due to incidental supercooling or to freeze point depression, but to tolerance of slow extracellular freezing (cooling rate: $2^{\circ} \mathrm{C} / \mathrm{h}$ ). The results indicated that ABA can induce some levels of freezing tolerance in rice seedlings although the level of tolerance induced was less than the case of cell cultures.

\section{Discussion}

The results clearly indicate that ABA can induce some level of freezing tolerance in suspension cultures and seedlings of rice. The levels of maximal freezing tolerance induced $\left(\mathrm{LT}_{50}\right)$ were $-9^{\circ} \mathrm{C}$ in cultured cells and $-4^{\circ} \mathrm{C}$ in seedlings, which were about $7-8^{\circ} \mathrm{C}$ and $2^{\circ} \mathrm{C}$ below the $\mathrm{LT}_{50}$ of the respective control. The observed survival was not due to temporary supercooling or freezing point depression but to the tolerance of slow extracellular freezing and ascertained by regrowth capability as well as TTC reduction tests and electrolyte leakage tests. Induced freezing tolerance in suspension cells was more than that $\left(\mathrm{LT}_{50}:-6.5 \sim-8^{\circ} \mathrm{C}\right)$ of in vitro grown Arabidopsis plants after 4-8 days of cold acclimation at $2-4^{\circ} \mathrm{C}[10,11]$. Rice seedlings have been known to be chilling-sensitive and unable to undergo cold acclimation in response to temperatures slightly above $0^{\circ} \mathrm{C}$ [25]. Our results confirm that rice suspension cells are seriously injured by exposure to $4^{\circ} \mathrm{C}$ (Figure 1). To our knowledge, this is the first paper describing that $\mathrm{ABA}$ can confer freezing tolerance in such a chilling-sensitive plant system. Many studies have shown that prior exogenous application of ABA reduced the level of chilling injuries in chilling-sensitive plants (e.g., [30,31]), but none of them attempted to measure freezing tolerance of such chilling-sensitive plant systems treated with ABA.

In contrast to rice suspension cells, suspension cells derived from smooth bromegrass (cold hardy grass) were not only tolerant to exposure to $4^{\circ} \mathrm{C}$ but also able to resume growth at $4^{\circ} \mathrm{C}$ (Figure 1). At the optimal conditions, exogenous $\mathrm{ABA}$ induced extremely high levels of freezing tolerance $\left(\mathrm{LT}_{50}:-28 \sim-35^{\circ} \mathrm{C}\right)$ in bromegrass cells $[7,18]$. Compared to bromegrass, the level of freezing tolerance induced $\left(\mathrm{LT}_{50}:-9^{\circ} \mathrm{C}\right)$ was much less in rice suspension cells. Yet, detailed comparison of the conditions for ABA-induced freezing tolerance in rice and bromegrass systems allowed us to find many shared commonalities. For example, the level of ABA-induced freezing tolerance was influenced by incubation period (optimum: 7-10 days), ABA concentration (optimum: $75 \mu \mathrm{M}$ or more) and cell inoculum size (optimal cell inoculum: $0.5-1 \mathrm{~g} / 50 \mathrm{~mL}$ medium) and was unaffected by light conditions, shaker speed (Figures 2, 3, 4, 5, 6). Induction of freezing tolerance by ABA in both systems occurred at non-hardening temperatures, having the optimum temperature at $25-30^{\circ} \mathrm{C}$ and did not require any exposure to low temperatures [7]. Both bromegrass and rice cells grew well in the presence of $A B A$ at these temperatures (Figure 5). The highest level of ABAinduced freezing tolerance was achieved where the greatest growth was attained in both systems [7]. In bromegrass cells, ABA induced cross-adaptation conferring heat, osmotic, salt tolerance and freezing tolerance simultaneously [18]. In rice cells, it was shown that heat tolerance was increased by ABA besides freezing tolerance (Figure 7).

Microscopic observation of rice cells during this process revealed that ABA-treated cells tended to have 

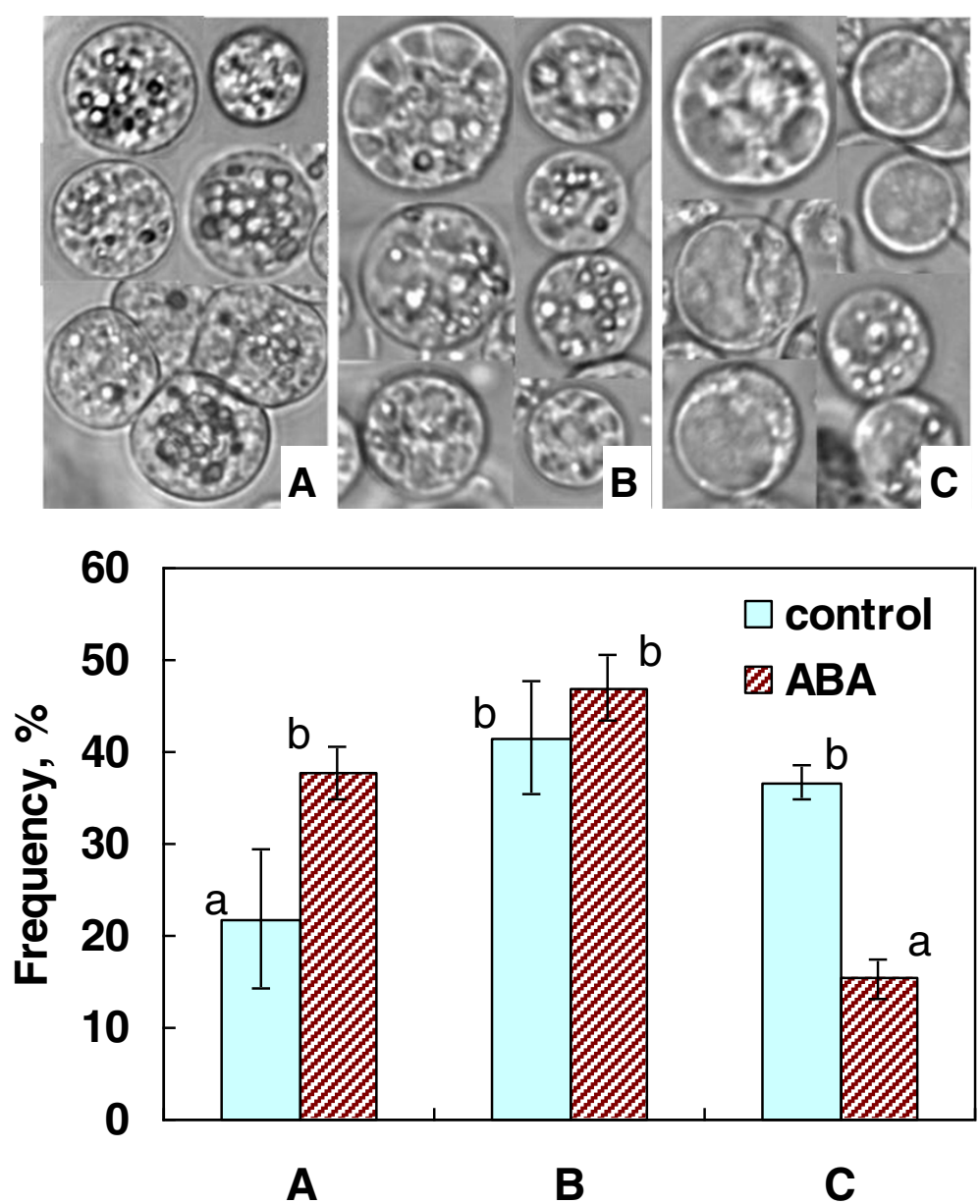

\section{Cell morphology}

Figure 9 Differences in cellular morphology types (A-C) of protoplasts isolated from rice suspension cells grown in the presence or absence of $\mathbf{A B A}$ at $25^{\circ} \mathbf{C}$ for $\mathbf{7}$ days. Typical examples of protoplasts for each morphology category (A: augmented; $\mathbf{B}$ : less vauolated; C: highly vacuolated) were shown on top of the graph. Values indicated by different letters (a-b) were significantly different $(a=0.05)$ using Tukey-Kramer multiple comparison analyses.

more augmented cytoplasm with increased intracellular particles and/or reduced vacuole sizes compared to control cells (Figure 9). This was accompanied by concomitant increases of osmolarity and decreases of water content in ABA-treated cells (Figure 8) [7]. These characteristics of the cells are typical of cold-acclimated cells [1] but they are also typical of cells in developing and ripening seed embryos where ABA plays important roles [32]. As discussed above, both rice and bromegrass suspension cells acquire freezing tolerance at $25-30^{\circ} \mathrm{C}$ where they maintained high growth rates even in the presence of ABA. It is interesting to note that seed development and maturation proceed well in the presence of intrinsic $\mathrm{ABA}$ at $25-30^{\circ} \mathrm{C}[32,33]$. Our recent proteomic analyses of rice suspension cells treated with or without ABA have revealed that ABA induced new sets of proteins in 2-7 days and protein profiles of ABA- treated cells were similar to that of rice seed embryos (manuscript in preparation).

As reviewed in the Background section, endogenous ABA has been known to increase during cold acclimation in cold hardy plants [2-5], which led to the hypothesis that ABA may work as an activator of triggering cold acclimation [6]. Molecular analyses of low temperature-responsive genes in Arabidopsis have revealed that there are at least ABA-dependent and ABAindependent transcriptional pathways $[15,16]$ and even cross-talks between these pathways [17]. This may partly prove the contribution of ABA in cold acclimation and yet numerous questions still remained unanswered. In Arabidopsis suspension cells, for example, exogenous ABA treatment did not confer freezing tolerance (our unpublished data). In contrast, in some plant cell cultures derived from cold hardy plant species such as 
A
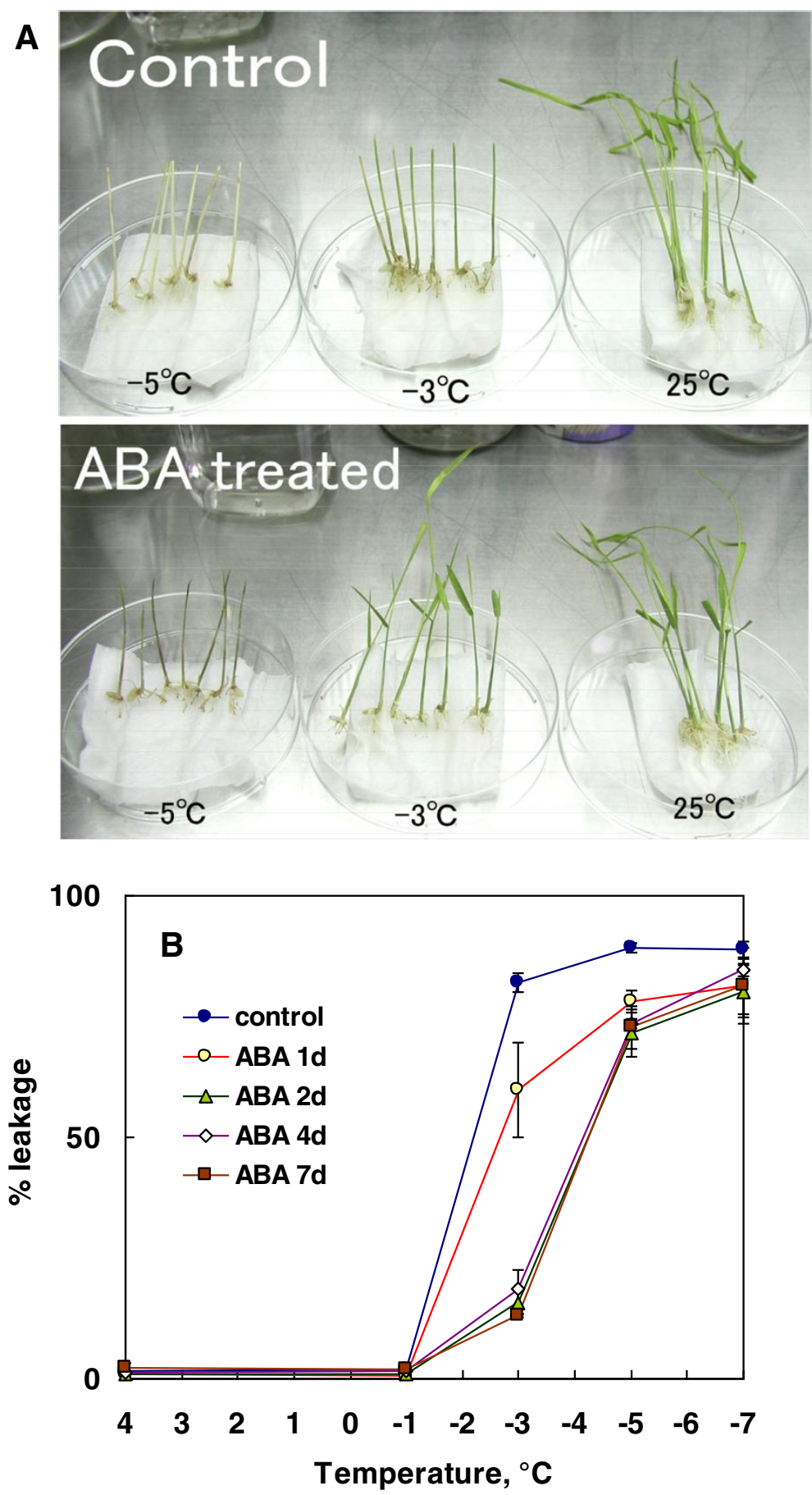

Figure 10 Effect of ABA on freezing tolerance of in vitro grown rice seedlings. Rice seedlings were grown aseptically in vitro for 8 days under normal conditions at $25^{\circ} \mathrm{C}$ followed by 1-7 day-incubation in the presence of $75 \mu \mathrm{M} \mathrm{ABA}$ and used for freeze tests as described in the Methods. Survival was determined by regrowth of the seedlings ( $\mathbf{A}$ : the result of 4 day-incubation with $A B A$ ) and by electrolyte leakage of detached leaves (B).

bromegrass and wheat, exogenous ABA induced much higher levels of freezing tolerance than did cold treatments [7,34]. Galiba et al. [34] found that exogenous ABA treatment allowed calli derived from various wheat cultivars to attain similarly high levels of freezing tolerance irrespective of freezing tolerance levels induced by cold treatment. Why do these things happen and how should they be interpreted? Does freezing tolerance induction by $\mathrm{ABA}$ and cold involve different mechanisms? 
Our previous studies on ABA-induced freezing tolerance in bromegrass suspension cells have shown that ABA-induced freezing tolerance is different from the one induced by low temperatures. For instance, physiological conditions such as the optimal temperatures were different between ABA and cold-induced ones as discussed above and cell morphology was also different [7]. Great differences were observed in gene expression profiles [21] and protein profiles $[19,20,35,36]$ between the two freezing tolerance induction systems. Ishikawa et al. [7] considered that a physiological process similar to seed formation/maturation proceeds in ABA-treated bromegrass cells, which confers various stress tolerance concurrently. Our current results clearly show that ABA can induce some levels of freezing tolerance in a chilling-sensitive plant system that lacks the ability to undergo cold acclimation. This will be another piece of evidence that ABA-induced freezing tolerance is elicited by mechanisms different from the low temperature-induced cold acclimation process, perhaps mimicking seed development and maturation. And yet, the level of freezing tolerance induced in rice by ABA was much less than the case of cold hardy bromegrass cells, the reasons of which require further investigation.

The level of freezing tolerance induced by $\mathrm{ABA}$ in rice seedlings was less $\left(\mathrm{LT}_{50}:-4^{\circ} \mathrm{C}\right)$ than that in suspension cells $\left(\mathrm{LT}_{50}:-9^{\circ} \mathrm{C}\right)$. This also holds true with cold hardy plant systems such as bromegrass or wheat cell cultures and their corresponding seedlings. Proteomic analyses revealed that similar proteins were induced in both rice cell cultures and seedlings treated with ABA (manuscript in preparation). Both in bromegrass [7] and rice suspension cells (Figure 5), cell cultures treated with ABA showed active growth at ambient temperatures and the level of freezing tolerance induced was proportional to the amount of growth. In contrast, ABA treatment retarded or stopped the growth of rice seedlings (data not shown). The limited levels of freezing tolerance acquired in ABA-treated seedlings may be related to the controlled or restricted manner of growth and differentiated functions of various types of cells in the seedlings. ABA-induced freezing tolerance may likely be best expressed in cultured cells or undifferentiated dividing cells if it involves a process similar to seed development and maturation.

\section{Conclusions}

The results clearly indicate that exogenous ABA induces some levels of freezing tolerance (maximum $\mathrm{LT}_{50}:-9^{\circ} \mathrm{C}$ and $-4^{\circ} \mathrm{C}$, respectively) in rice suspension cells and seedlings. The survival was not due to temporary supercooling but to the tolerance of slow extracellular freezing and ascertained by regrowth capability. ABA treatment also induced heat tolerance. The optimum conditions for ABAinduced freezing tolerance in rice cells and those in cold hardy bromegrass cells were similar. ABA-induced freezing tolerance was best achieved at $25-30^{\circ} \mathrm{C}$ where the cells maintained high growth even in the presence of ABA. This is probably the first paper reporting that ABA can confer some levels of freezing tolerance in a chilling sensitive plant system that lacks the ability to undergo cold acclimation. This provides further evidence that ABA-induced freezing tolerance is elicited by mechanisms different from the low temperature-induced cold acclimation process.

\section{Methods}

\section{Cell cultures}

Experiments were mainly conducted with a nonembryogenic cell suspension culture (line: OcN6) of rice (Oryza sativa L.), that had been derived from rice Oc suspension culture [37] and subcultured for more than two years following acclimation to N6 medium [38]. The original medium for the Oc culture was 2,4-D supplemented MS $[37,39]$, but when we obtained this culture, the culture was maintained in a medium containing GA and BA, which are known to inhibit freezing tolerance induction by ABA [40]. Simpler media containing 2,4-D as the sole hormone were preferred. For this reason, the stock culture was transferred to $\mathrm{N} 6$ medium $(\mathrm{OcN} 6)$ and maintained at $25^{\circ} \mathrm{C}$ on a rotary shaker (85 rpm) by biweekly subculturing in $50 \mathrm{~mL}$ of $\mathrm{N6}$ medium (pH 5.8 with $3 \% \mathrm{w} / \mathrm{v}$ sucrose and 1 ppm 2,4-D).

In chilling experiments, a suspension culture of smooth bromegrass (Bromus inermis cv. Manchar) was used as the control representing cold hardy plant cells to compare with rice cells. Bromegrass suspension cells were maintained in ER medium (0.5 ppm 2,4-D) at $25^{\circ} \mathrm{C}$ as described previously [7].

\section{Culture conditions for $A B A$ treatment}

Individual experiments were initiated with one $g$ fresh weight of rice suspension cells from 7 day-old stock cultures unless otherwise specified. In typical experiments, cells were incubated in $50 \mathrm{~mL}$ of medium with $75 \mu \mathrm{M}$ ABA (treated) or without ABA (control) on a rotary shaker $(85 \mathrm{rpm})$ at $25^{\circ} \mathrm{C}$ for 7 days.

To find optimal conditions for ABA-induced freezing tolerance, the effect of cell inoculum size $(0.5,1,1.5 \mathrm{~g})$, ABA concentration $(0-75 \mu \mathrm{M})$, shaker speed $(85,100$ and $120 \mathrm{rpm})$, incubation temperature $\left(25,28,30^{\circ} \mathrm{C}\right)$, the presence of light $\left(50 \mu \mathrm{mol} \mathrm{s}{ }^{-1} \mathrm{~m}^{-2}\right)$ and inclusion of $3 \%$ $(\mathrm{w} / \mathrm{v})$ sucrose in the freezing medium were checked. Cells were usually incubated with or without ABA for 7 days before determination of freezing tolerance. When necessary, time course-dependent changes in freezing tolerance were also determined.

\section{Chilling tests for suspension cells}

Rice or bromegrass suspension cells $(0.25 \mathrm{~g}$ inoculated in $12.5 \mathrm{~mL}$ of respective culture medium with or without 
$75 \mu \mathrm{M}$ ABA) were pre-incubated at $25^{\circ} \mathrm{C}$ for 2 days (shaker speed: $85 \mathrm{rpm}$ ). Then the cells were incubated at $4^{\circ} \mathrm{C}$ for $0-10$ days (shaker speed: $85 \mathrm{rpm}$ ) in the dark. Following the chilling treatment, the cells were reincubated at $25^{\circ} \mathrm{C}$ for 5 days prior to harvest. The harvested cells were washed with ample water and cell dry weight was determined after oven-drying at $70^{\circ} \mathrm{C}$ for 2 days. Survival\% was determined by regrowth of chilled cells compared to that of non-stressed cells and 100\% dead cells as detailed elsewhere [18].

To unravel growth characteristics of bromegrass suspension cells during prolonged incubation at low temperature, bromegrass cultures $(0.25 \mathrm{~g}$ cells in $12.5 \mathrm{~mL}$ of ER medium) were incubated at $4^{\circ} \mathrm{C}$ for $1-3$ weeks in the presence or absence of ABA before determining fresh weight increases as compared to the initial cell inoculum.

\section{Freeze tests for suspension cells}

Following incubation under designated culture conditions with or without ABA, cells from a flask were harvested by filtration and washed with $250 \mathrm{~mL}$ of sterilized distilled water to remove residual medium, which otherwise would affect freezing and heat tolerance levels [7,18]. For regrowth analyses, $0.25 \mathrm{~g}$ fresh weight of cells were placed in a $15 \mathrm{~mL}$ pre-sterilized tube with $0.1 \mathrm{~mL}$ of sterile water for each test temperature (triplicates). The cells were icenucleated at $-3^{\circ} \mathrm{C}$ by touching the tube with dry ice. Frozen cells were held at $-3^{\circ} \mathrm{C}$ for $1 \mathrm{~h}$ and then cooled at $2^{\circ} \mathrm{C} / \mathrm{h}$ to $-12^{\circ} \mathrm{C}$, and from -12 to $-21^{\circ} \mathrm{C}$ at $5^{\circ} \mathrm{C} / \mathrm{h}$. Cells were removed at designated test temperatures and thawed at $4^{\circ} \mathrm{C}$ prior to evaluating viability. Both control and ABAtreated cells were killed by direct submersion in liquid nitrogen followed by rapid thawing for several cycles. All these procedures were done aseptically.

In some freeze tests, rice cells were frozen in the presence of $3 \%(\mathrm{w} / \mathrm{v})$ sucrose $(0.1 \mathrm{~mL})$ instead of sterile water and processed in the same manner to see the effect of sucrose on the freeze-survival.

\section{Heat tests for suspension cells}

Cultures, initiated with $1 \mathrm{~g}$ fresh weight inocula in $50 \mathrm{~mL} \mathrm{N6}$ medium, were incubated at $25^{\circ} \mathrm{C}$ for 7 days with or without $75 \mu \mathrm{M}$ ABA. Cell sampling was done as described in the freezing tolerance section except a heat stress was imposed by incubating cells in a water bath at $43^{\circ} \mathrm{C}$ from 0 to $180 \mathrm{~min}$. Following the heat treatment, cells were placed at $4^{\circ} \mathrm{C}$ overnight prior to assaying viability. Dead cells were obtained by submerging the cells in liquid nitrogen followed by rapid thawing for several cycles or by boiling the cells for $5 \mathrm{~min}$ at $100^{\circ} \mathrm{C}$.

\section{Determination of viability}

Following each stress treatment, $0.25 \mathrm{~g}$ fresh weight of cells for each designated condition (triplicates) were incubated in $12.5 \mathrm{~mL}$ of culture medium at $25^{\circ} \mathrm{C}$ in the dark. After 7 days incubation, the final fresh weight of cells in the exponential growth phase was determined. Under these growth conditions, rice cells showed a linear relationship $(r=0.989)$ between the final fresh weight and the cell inoculum fresh weight ranging from 0.03 to $0.34 \mathrm{~g}[7,18]$.

TTC reduction assays were conducted as described previously [18]. Briefly, following freeze-thaw cycles, cells $(0.3 \mathrm{~g})$ were washed with $5 \mathrm{~mL}$ of sterile water for 3-4 h (this washing process was necessary to avoid erroneously high survival values) before being placed in $4 \mathrm{~mL}$ of TTC solution $(0.08 \%$ TTC in $0.05 \mathrm{M}$ potassium phosphate buffer, $\mathrm{pH} 7.5$ ) for $24 \mathrm{~h}$ at $25^{\circ} \mathrm{C}$ in the dark. Following removal of TTC solution, the cells were extracted with $5 \mathrm{~mL}$ of $95 \%$ ethanol for 2 days and absorbance read at $485 \mathrm{~nm}$.

Freezing tolerance was represented as the $\mathrm{LT}_{50}$, the lethal temperature at which there was a $50 \%$ decrease in the survival compared to the non-stressed control (TTC, regrowth tests), unless otherwise specified. All viability assays were done in triplicate.

\section{Determination of cell growth}

Following incubation of rice suspension cultures under the designated conditions, cells were harvested by filtration on a mesh filter, rinsed well with $250 \mathrm{~mL}$ of water and blotted on paper towel for $1 \mathrm{~min}$ before determination of fresh weight. Dry weights were determined after oven-drying at $70^{\circ} \mathrm{C}$ for 2 days.

\section{Determination of water content and osmolarity}

Following incubation of rice suspension cultures at $25^{\circ} \mathrm{C}$ for 7 days with or without $75 \mu \mathrm{M} A B A$, cells were harvested by filtration on a mesh filter, rinsed well with $250 \mathrm{~mL}$ of water. The cells were placed into a syringe and centrifuged at $1500 \mathrm{rpm}$ for $10 \mathrm{~min}$ to remove extracellular water before determination of cell fresh weight and osmolarity. Dry weight of a part of the centrifuged cells was determined by oven-drying at $70^{\circ} \mathrm{C}$ for 2 days and water content was expressed on a dry weight basis. The syringe with the remainder of the cells was placed into LN and rewarmed at room temperature before being squeezed to obtain the cell sap. The cell sap was centrifuged at $10000 \mathrm{rpm}$ for $10 \mathrm{~min}$ and osmolarity of the supernatant was determined with a vapor pressure osmometer (Wescor, Inc).

\section{Microscopic observation of rice suspension cells}

Rice suspension cells existed as cell clumps (each clump composed of ca. 50-100 cells). This made it difficult to observe the morphological structure of individual cells except for the cells in the peripheral zone of a clump, which might represent only a portion of structural 
changes. Instead, we observed protoplasts isolated from the cell clumps for morphological studies. The aseptically harvested rice cells following incubation with or without $75 \mu \mathrm{M} \mathrm{ABA}$ at $25^{\circ} \mathrm{C}$ for 7 days were used for protoplast isolation. Cells were incubated in medium containing $0.5 \mathrm{M}$ sorbitol, $5 \mathrm{mM}$ MES (pH 5.5), $1 \mathrm{mM}$ $\mathrm{CaCl}_{2}, 1 \%(\mathrm{w} / \mathrm{v})$ Cellulase R-10 (Kinki Yakuruto) and $0.1 \%(w / v)$ Pectolyase (Seishin Pharmaceutical) in a Petri dish at room temperature for $10 \mathrm{~h}$. Following gentle agitation, the medium was passed through a nylon mesh to obtain protoplast solution. Following washing with $0.5 \mathrm{M}$ sorbitol, $1 \mathrm{mM} \mathrm{CaCl}_{2}$, the protoplasts were observed under microscopy and photographed. The cell morphology of 150 or more protoplasts for each treatment was classified into three categories based on the extent of vacuolation and augmentation of cytoplasm (Figure 9).

\section{Freeze tests for rice seedlings}

Rice (O. sativa L. cv. Nipponbare) seeds were hulled and sterilized with $10 \%(\mathrm{v} / \mathrm{v})$ sodium hypochlorite solution (active chlorine concentration: ca 1\%) for $15 \mathrm{~min}$ and grown aseptically on semi-solid MS medium containing $0.8 \%(\mathrm{w} / \mathrm{v})$ agar and $3 \%(\mathrm{w} / \mathrm{v})$ sucrose for 8 days under light conditions $\left(50 \mu \mathrm{mol} \mathrm{s}{ }^{-1} \mathrm{~m}^{-2}\right)$ at $25^{\circ} \mathrm{C}$. Then they were grown in the presence of $75 \mu \mathrm{M} \mathrm{ABA}$ for additional 4 days or $1-7$ days at $25^{\circ} \mathrm{C}$ before used for determination of freezing tolerance. Seedlings grown for 9 days from seeds without ABA were used as control plants.

Rice seedlings (five for each test temperature) grown as described above were rinsed well with sterilized water, then trimmed to have about $5 \mathrm{~cm}$ of shoots and $1 \mathrm{~cm}$ of roots and wrapped with water-soaked Kimwipe sheet. They were placed in $50 \mathrm{~mL}$ pre-sterilized plastic centrifuge tubes with $1 \mathrm{~mL}$ of water in the bottom. All these processes were done aseptically in a laminar flow chamber. The tubes were placed in a cool-bath held at $-1^{\circ} \mathrm{C}$, ice-inoculated with the liquid nitrogen cooled rods. After double-checking the freezing of the water inside the tube and held there for $1 \mathrm{~h}$ before being cooled by $2^{\circ} \mathrm{C} / \mathrm{h}$ to $5^{\circ} \mathrm{C}$. At designated temperatures $\left(-3\right.$ and $\left.-5^{\circ} \mathrm{C}\right)$, the tubes were taken out from the bath and placed at $4^{\circ} \mathrm{C}$ for thawing. Then the tubes with plants were incubated at $25^{\circ} \mathrm{C}$ for 14 days before determining visually the regrowth and injuries.

To determine freezing tolerance of leaves, they were excised from seedlings grown in vitro as described above with or without ABA. The excised leaves were wrapped with water-soaked Kimwipe sheet and placed in $15 \mathrm{~mL}$ presterilized tubes. Following incubation at $-1^{\circ} \mathrm{C}$, they were ice-inoculated and held there for $30 \mathrm{~min}$, then cooled by $2^{\circ} \mathrm{C} / \mathrm{h}$ to designated temperatures. Following slow thawing at $4^{\circ} \mathrm{C}, 3 \mathrm{~mL}$ of sterile water was added to each test tube and incubated overnight at $25^{\circ} \mathrm{C}$ before determining the conductivity of the leachate $\left(\mathrm{C}_{1}\right)$ using a Horiba conductivity meter DS-12. Conductivity of the same samples after autoclaving at $105^{\circ} \mathrm{C}$ for $1 \mathrm{~min}$ was also measured $\left(\mathrm{C}_{2}\right)$. Percentage leakage was calculated from $\left(\mathrm{C}_{1}-\mathrm{C}_{\mathrm{w}}\right) /\left(\mathrm{C}_{2}-\mathrm{C}_{\mathrm{w}}\right)$, where $\mathrm{C}_{\mathrm{w}}$ was the conductivity of water.

\section{Experimental design and data presentation}

The experiments were replicated three times or more and the data are presented as the mean \pm SD. When necessary, Tukey-Kramer multiple comparison tests were performed to show statistically significant differences at 5\% level (Figures 1, 5, 8 and 9).

\section{Definitions}

Cold hardiness, resistance to subfreezing temperatures by tolerating extracellular freezing (freezing tolerance) or by avoiding freezing (such as transient and deep supercooling); cold acclimation, acquisition of cold hardiness in response to non-lethal low temperatures alone or in combination with short photoperiods; chilling temperatures, low temperature ranges above $0^{\circ} \mathrm{C}$ (e.g., $0-10^{\circ} \mathrm{C}$ ); chilling injury, injury caused by exposure to chilling temperatures; chilling-sensitive or tolerant, sensitive or tolerant to chilling temperatures.

\section{Abbreviations}

ABA: Abscisic acid; $\mathrm{LT}_{50}$ : 50\% killing temperature; TTC: 2,3,5-triphenyl tetrazolium chloride.

\section{Competing interests}

The authors declare that they have no competing interests.

\section{Authors' contributions}

RS, AM, KA and RM contributed equally to this work by conducting most of the freeze tests and by optimizing the ABA-induced freezing tolerance in rice cultures and seedlings. HM studied the cold hardiness of rice seedlings. KK participated in coordination and supervision. MI conceived of the study, supervised the study and drafted the manuscript. All authors read and approved the final manuscript.

\section{Acknowledgments}

We thank Ms. H. Nakatani, Y. Koike, R. Iwanami and Y. Yamakawa of NIAS for their technical assistance and Dr. Duncan Vaughan (NIAS) for critically reading the manuscript. This study was mainly supported by MAFF grants (Rice Genome Project MA-2121 and PR-1207) and partially by a PRBRAIB grant from BRAIN, Japan and grants-in-aid for scientific research (17658011 and 16380030) from JSPS to M.I.

\section{Author details}

${ }^{1}$ Division of Plant Sciences, National Institute of Agrobiological Sciences, Kannondai 2-1-2, Tsukuba 305-8602, Ibaraki, Japan. ${ }^{2}$ Applied Biological Science, Graduate School of Science and Technology, Tokyo University of Science, Yamazaki 2641, Noda 278-8510, Chiba, Japan.

Received: 22 February 2013 Accepted: 29 August 2013 Published: 3 September 2013

\section{References}

1. Sakai A, Larcher W: Frost Survival of Plants. Responses and Adaptation to Freezing Stress. (Ecological Studies 62). Berlin: Springer-Verlag; 1987.

2. Chen HH, Li PH, Brenner ML: Involvement of abscisic acid in potato cold acclimation. Plant Physiol 1983, 71:362-365. 
3. Lang V, Mantyla E, Welin B, Sundberg B, Palva ET: Alterations in water status endogenous abscisic acid content and expression of rab18 gene during the development of freezing tolerance in Arabidopsis thaliana. Plant Physiol 1994, 104:1341-1349.

4. Holappa LD, Walker-Simmons MK: The wheat abscisic acid-responsive protein kinase mRNA, PKABA1, is up-regulated by dehydration, cold temperature, and osmotic stress. Plant Physiol 1995, 108:1203-1210.

5. Lalk I, Dörffing K: Hardening, abscisic acid, proline and freezing resistance in two winter wheat varieties. Physiol Plant 1985, 63:287-292.

6. Chen HH, Gusta LV: Abscisic acid-induced freezing tolerance in cultured plant cells. Plant Physiol 1983, 73:71-75.

7. Ishikawa M, Robertson AJ, Gusta LV: Effect of temperature, light, nutrients and dehardening on abscisic acid induced cold hardiness in Bromus inermis Leyss suspension cultured cells. Plant Cell Physiol 1990, 31:51-59.

8. Keith CN, McKersie BD: The effect of abscisic acid on freezing tolerance of callus cultures of Lotus corniculatus L. Plant Physiol 1986, 80:766-769.

9. Orr W, Keller WA, Singh J: Induction of freezing tolerance in an embryogenic cell suspension culture of Brassica napus by abscisic acid at room temperature. J Plant Physiol 1986, 126:23-32.

10. Heino P, Sandman G, Lang V, Nordin K, Palva ET: Abscisic acid deficiency prevents development of freezing tolerance in Arabidopsis thaliana. Theor Appl Genet 1990, 79:801-806.

11. Gilmour SJ, Thomashow MF: Cold acclimation and cold-regulated gene expression in ABA mutants of Arabidopsis thaliana. Plant Mol Biol 1991, 17:1233-1240

12. Mantyla E, Lang V, Palva ET: Role of abscisic acid in drought-induced freezing tolerance, cold acclimation and accumulation of LTI78 and RAB18 proteins in Arabidopsis thaliana. Plant Physiol 1995, 107:141-148.

13. Thomashow MF: Plant cold acclimation, freezing tolerance genes and regulatory mechanisms. Annu Rev Plant Physiol Plant Mol Biol 1999, 50:571-599.

14. Nordin K, Heino P, Palva ET: Separate signal pathways regulate the expression of a low-temperature-induced gene in Arabidopsis thaliana (L.) Heynh. Plant Mol Biol 1991, 16:1061-1071.

15. Yamaguchi-Shinozaki K, Shinozaki K: A novel cis-acting element in an Arabidopsis gene is involved in responsiveness to drought, low temperature or high-salt stress. Plant Cell 1994, 6:251-264.

16. Shinozaki K, Yamaguchi-Shinozaki K, Seki M: Regulatory network of gene expression in the drought and cold stress responses. Curr Opin Plant Biol 2003, 6:410-417

17. Ishitani M, Xiong L, Stevenson B, Zhu JK: Genetic analysis of osmotic and cold stress signal transduction in Arabidopsis: interactions and convergence of abscisic acid-dependent and abscisic acid-independent pathways. Plant Cell 1997, 9:1935-1949.

18. Ishikawa M, Robertson AJ, Gusta LV: Comparison of viability tests for assessing cross-adaptation to freezing, heat and salt stresses induced by abscisic acid in bromegrass (Bromus inermis Leyss) suspension cultured cells. Plant Sci 1995, 107:83-93.

19. Robertson AJ, Gusta LV, Reaney MT, Ishikawa M: Protein synthesis in bromegrass (Bromus inermis Leyss.) cultured cells during the induction of frost tolerance by abscisic acid or low temperature. Plant Physiol 1987, 84:1331-1336.

20. Robertson AJ, Gusta LV, Reaney MJT, Ishikawa M: Identification of proteins correlated with increased freezing tolerance in bromegrass (Bromus inermis Leyss. Cv Manchar) cell cultures. Plant Physiol 1988, 86:344-347.

21. Nakamura T, Yazaki J, Kishimoto N, Kikuchi S, Robertson AJ, Gusta LV, Ishikawa M: Comparison of long-term up-regulated genes during induction of freezing tolerance by cold and ABA in bromegrass cell cultures revealed by microarray analyses. Plant Growth Reg 2013. http:// link.springer.com/journal/10725/onlineFirst/page/2

22. Satake T: Determination of the most sensitive stage to sterile type cool injury in rice plants. Res Bull Hokkaido Natl Agric Exp Stn 1976, 113:1-43.

23. Graham D, Patterson BD: Responses of plants to low, nonfreezing temperature: proteins, metabolism, and acclimation. Annu Rev Plant Physiol Plant Mol Biol 1982, 33:347-372.

24. Kawakami A, Sato Y, Yoshida M: Genetic engineering of rice capable of synthesizing fructans and enhancing chilling tolerance. J Exp Bot 2008, 59:793-802.

25. Sato Y, Murakami T, Funatsuki H, Matsuba S, Saruyama H, Tanida M: Heat shock mediated APX gene expression and protection against chilling injury in rice seedlings. J Exp Bot 2001, 52:145-151.

26. Bertin P, Kinet JM, Bouharmont J: Evaluation of chilling sensitivity in different rice varieties. Relationship between screening procedures applied during germination and vegetative growth. Euphytica 1996, 89:201-210.
27. Kasamo K, Yamaguchi M, Nakamura Y: Mechanism of the chilling-induced decrease in proton pumping across the tonoplast of rice cells. Plant Cell Physiol 2000, 41:840-849.

28. Mao D, Chen C: Colinearity and similar expression pattern of rice DREB1s reveal their functional conservation in the cold-responsive pathway. PLOS ONE 2012, 7:e47275.

29. Ishikawa M, Suzuki M, Nakamura T, Kishimoto T, Robertson AJ, Gusta LV: Effect of growth phase on survival of bromegrass suspension cells following cryopreservation and abiotic stresses. Ann Bot 2006, 97:453-459.

30. Rikin A, Gitler C, Atsmon C: Chilling injury in colon: light requirement for the reduction of injury and for the protective effect of abscisic acid. Plant Cell Physiol 1981, 22:453-460.

31. Xin Z, Li PH: Abscisic acid-induced chilling tolerance in Maize suspension-cultured cells. Plant Physio/ 1992, 99:707-711.

32. Taiz L, Zeiger E: Plant Physiology Fifth edition. Sunderland: Sinauer Associates; 2010.

33. Matsuo $T$, Kumazawa K, Ishii R, Ishihara K, Hirata H: Science of the Rice Plant, Vol 2 Physiology. Tokyo: Food and Agriculture Policy Research Center; 1995.

34. Galiba G, Tuberosa R, Kocsy G, Sutka J: Involvement of chromosomes 5A and $5 \mathrm{D}$ in cold-induced abscisic acid accumulation in and frost tolerance of wheat calli. Plant Breed 1993, 110:237-242.

35. Robertson AJ, Ishikawa M, Mackenzie SL, Gusta LV: Abscisic acid-induced heat tolerance in Bromus inermis Leyss cell suspension cultures. Heatstable, ABA-responsive polypeptides in combination with sucrose confer enhanced thermostability. Plant Physiol 1994, 105:81-190.

36. Dallaire S, Houde M, Gagne Y, Saini HS, Boileau S, Chevrier N, Sarhan F: ABA and low temperature induce freezing tolerance via distinct regulatory pathways in wheat. Plant Cell Physiol 1994, 35:1-9.

37. Baba A, Hasezawa S, Syono K: Cultivation of rice protoplasts and their transformation mediated by Agrobacterium spheroplasts. Plant Cell Physiol 1986, 27:463-471.

38. Chu CC, Wang CS, Sun CS, Hsu C, Yin CK, Chu CY, Bi FY: Establishment of an efficient medium for anther culture of rice through comparative experiments on the nitrogen sources. Sci Sin 1975, 18:659-668.

39. Murashige T, Skoog F: A revised medium for rapid growth and bio assays with tobacco tissue cultures. Physiol Plant 1962, 15:473-497.

40. Reaney MJT, Gusta LV: The effects of abscisic acid, kinetin, and gibberellin on freezing tolerance in smooth bromegrass (Bromus inermis) cell suspensions. Can J Bot 1989, 67:3640-3646.

doi:10.1186/1756-0500-6-351

Cite this article as: Shinkawa et al:: Abscisic acid induced freezing tolerance in chilling-sensitive suspension cultures and seedlings of rice. BMC Research Notes 2013 6:351.

\section{Submit your next manuscript to BioMed Central and take full advantage of:}

- Convenient online submission

- Thorough peer review

- No space constraints or color figure charges

- Immediate publication on acceptance

- Inclusion in PubMed, CAS, Scopus and Google Scholar

- Research which is freely available for redistribution 